\title{
ARE PUBLIC SECTOR WORKERS MORE RISK AVERSE THAN PRIVATE SECTOR WORKERS?
}

\author{
DON BELLANTE and ALBERT N. LINK*
}

\begin{abstract}
Available evidence suggests that stability of employment is greater in the public sector than in the private sector. The value that individuals place on this stability depends on the individual's degree of risk aversion. Economic reasoning suggests that, other things equal, those individuals with a high degree of aversion to risk will be more likely than others to seek employment in the public sector. This paper tests that hypothesis through the use of probit analysis and a measure of risk aversion developed in the University of Michigan's Panel Study of Income Dynamics. The results tend to confirm the hypothesis, implying that a policy of intersectoral equality of pay for comparable jobs would result in an excess supply of workers to the public sector.
\end{abstract}

\begin{abstract}
A NUMBER of recent studies by Sharon Smith, among others, have compared public sector and private sector pay levels. ${ }^{1}$ These studies conclude that government workers on average receive higher pay than workers in the private sector with equivalent human capital. ${ }^{2}$ If one assumes that workers

- Don Bellante is an associate professor of economics and Albert Link is an assistant professor of economics, both at Auburn University. They gratefully acknowledge helpful comments made by James E. Long.
\end{abstract}

\footnotetext{
'Sharon Smith, "Government Wage Differentials," Journal of Urban Economics, Vol. 4, No. 3 (July 1977), pp. 248-71; Sharon Smith, "Government Wage Differentials by Sex," Journal of Human $R e$ sources, Vol. 11, No. 2 (Spring 1976), pp. 185-99; and Sharon P. Smith, "Pay Differentials Between Federal Government and Private Sector Workers," Industrial and Labor Relations Review, Vol. 29, No. 2 (January 1976), pp. 179-97.

${ }^{2}$ This conclusion, when limited to wage rate compensation, does not hold up for each sex in each level of government. However, as we explain below, the
}

in the public and private sectors should be paid the same wages, holding human capital characteristics constant, then the amount of difference in sectoral pay levels also measures the amount of overpayment to public sector workers. The assumption, however, is problematic. Economic theory suggests that since characteristics of jobs differ, "equalizing differences" in pay will be generated so as to achieve comparability in the net advantage to being employed in various occupations.

Although documentation is sparse, it appears that working conditions are generally regarded as more favorable in public than in private employment. The fact that some characteristics of public sector jobs are more favorable can be documented. For example, fringe benefits are demonstrably more favorable, on average, in all levels of

conclusion holds for both sexes at all three levels of government when fringe benefits are added to wages. 
government employment than they are in private employment. ${ }^{3}$ Indeed, when data on fringe benefits are added to Smith's figures, it is found that public compensation exceeds private pay at all levels of government. ${ }^{4}$ More recently, Quinn found evidence that, in terms of Dictionary of Occupational Titles definitions, state and federal government jobs are on average more attractive than jobs in the private sector with regard to five characteristics: variety, repetitiveness, strength requirements, physical involvement, and the presence of a group of poor working conditions. ${ }^{5}$ Local government jobs also fared better than private sector jobs in comparisons of the first two characteristics. Whether the marginal local government worker considers his working conditions more or less favorable than private employment can thus not be definitively determined from Quinn's results.

Furthermore, earnings from government employment are usually thought to be more secure than earnings from private employment. Bloch and Smith demonstrated that the probability of becoming unemployed is considerably less for workers in the public sector than for those in the private sector, ceteris paribus. ${ }^{6}$ Hall, in fact, has estimated that for males the probability of becoming unemployed in the public sector is less than half the probability in the private sector.?

\footnotetext{
${ }^{3}$ Edward Friend, First National Survey of Employee Benefits of Full-Time Personnel of U.S. Municipalities (Washington, D.C.: Labor Management Relations Service, 1972); U.S. Bureau of Labor Statistics, State Government Employee Compensation 1972, Rulletin 1899 (Washington, D.C.: G.P.O., 1976); and U.S. General Accounting Office, Report to Congress, Need for a Comparability Policy for both Pay and Benefits of Federal Civilian Employees, F.P.C.D.-75-62 (Washington, D.C.: G.P.O., July 1, 1975).

'Don Bellante and Mark Jackson, Labor Economics: Choice in Labor Markets (New York: McGraw-Hill, 1979), pp. $249-51$

Joseph Quinn, "Wage Differentials Among Older Workers in the Public and Private Sectors," Journal of Human Resources, Vol. 14, No. 1 (Winter 1979), pp. $55-57$.

6Farrell Bloch and Sharon Smith, "Human Capital and Labor Market Employment," Journal of Human Resources, Vol. 14, No. 2 (Spring 1979), pp. 550-60.

'Robert Hall, "Turnover in the Labor Force," in Brookings Papers on Economics Activity (Washington, D.C.: The Brookings Institution, 1972), pp. $709-56$.
}

In light of this empirical evidence, we should expect that innately more risk averse individuals have a preference for public sector employment, ceteris paribus. While such a conclusion flows directly from utility-maximization principles, the relation has never been demonstrated empirically. Accordingly, the purpose of this note is to investigate the relation between risk aversion and choice of sector of employment.

\section{Model and Analysis}

It is assumed that when an individual chooses a sector of employment, broadly defined here as the public or private sector, he is in effect choosing a specific set of jobrelated characteristics. Among these many characteristics is the degree of financial risk associated with the sector of employment, one index of such financial risk being the probability of becoming unemployed. Our hypothesis is that innately risk-averse individuals will have a greater propensity to choose the less risky sector, that is, the public sector.

The economic literature is replete with studies of occupational choice; however, to our knowledge these studies have not addressed the choice of public or private sector employment. ${ }^{8}$ Common to these studies is the hypothesis that the relevant human capital-demographic variables to consider in explaining occupational choice are education, job experience or age, marital status, family size, race, and sex. We have included an additional variable: the individual's innate tendency toward risk aversion.

Our empirical analysis is based on a sample of 3643 working heads of household from the Panel Study of Income Dynamics,

\footnotetext{
${ }^{8}$ Michael Boskin, "A Conditional Logit Model of Occupational Choice," Journal of Political Economy, Vol. 82, No. 2 (March/April 1974), pp. 389-98; Abraham Haspel, "A Study in Occupational Choice: Managerial Positions," Southern Economic Journal, Vol. 44, No. 4 (April 1978), pp. 958 - 67; Peter Schmidt and Robert Strauss, "Estimation of Models with Jointly Dependent Variables: A Simultaneous Logit Ap. proach," Econometrica, Vol. 43, No. 4 (July 1975), pp. 745-55; and Schmidt and Strauss, "The Prediction of Occupation Using Multiple Logit Models," International Economic Review, Vol. 16, No. 2 (June 1975), pp. $471-86$.
} 
prepared by the Survey Research Center of the University of Michigan, for the year 1972. Each individual was classified as working in either the public (nonmilitary) or the private sector (SOE). Public sector employees were coded by the number 1 , and private sector employees were coded by the number 0. Each individual's age $(A G E)$ and education $(E D)$ were measured in years. ${ }^{9}$ Work experience $(E X P)$ was calculated as age less education less five. Marital status (MS) was measured as a binary variable with individuals currently married coded 1 and those not currently married coded 0 . Family size $(F S)$ was measured by the number of dependents living with the head of household. Race $(R A C E)$ and sex (SEX) were measured by binary variables. The number 0 was given to whites and to males, and the number 1 was given to nonwhites and to females.

The Panel Study reports an index of innate risk aversion $(R A)$ for each head. This index is formulated on the basis of answers to questions involving the condition and insurance of automobiles owned, the use of seat belts, the head's extent of medical coverage, and the head's smoking and drinking habits. This index ranges from 0 to 9 , where 9 represents the highest level of risk aversion. The use of this index to proxy risk aversion can easily be criticized. The index has been derived on the basis of revealed consumer behavior for insuring against unexpected changes in one's material possessions and physical health and, for that fact, it may partially reflect an ability rather than a propensity to avert risk. Nevertheless, the index has been used in at least one other study and did perform as theoretically predicted. ${ }^{10}$

${ }^{9}$ The head of household was asked, "How many grades of school did you finish?" Possible responses were as follows (with number of actual responses in parentheses):

1. $0-5$ grades (3)

2. $6-8$ grades (7)

3. 9 - 11 grades (10)

4. 12 grades (12)

5. 12 grades plus nonacademic training (14)

6. College, no degree (15)

7. College, degree (16)

8. College, advanced or professional degree (18)

${ }^{10}$ Robert Feinberg, "Risk Aversion, Risk, and the
The probability of choosing public sector employment was estimated in terms of these independent variables:

(1) $\begin{gathered}S O E= \\ f\left(E D, A G E, A G E^{2}, M S, F S,\right. \\ R A C E, S E X, R A)\end{gathered}$

The squared $A G E$ variable is included to account for any possible nonlinear effect. An alternative form of Equation 1, Equation $1^{\prime}$, was also estimated using EXP and $E X P^{2}$ rather than $A G E$ and $A G E^{2}$. Equations $l$ and $l^{\prime}$ were estimated by probit analysis and the results are shown in the first two columns of the table.

Both equations are statistically significant at the one percent level or better as measured by the likelihood ratio test. ${ }^{11}$ The reported probit coefficients and their significance level reveal the direction of the influence of the associated independent variable with the dependent variable; however, they can not be interpreted directly as partial derivatives. There is a systematic relationship between a probit coefficient and its corresponding partial derivative. ${ }^{12}$ The partial derivatives are evaluated, at the mean, and are reported in the last two columns of the table. Since these estimates are almost identical for Equations 1 and $1^{\prime}$, only the results from Equation 1 are discussed in detail.

The estimated coefficient on $E D$ is statistically significant at the one percent level or better and its partial derivative implies that a one-year increase in education increases the probability of selecting public sector employment by 0.5 percentage points. The influence of $A G E$ is also statistically significant at the one percent level or better. Increases in $A G E$ increase the probability of employment in the public sector until about age 50 and then the influence decreases. Clearly, the lower age group represents the majority of the work force. The impact of $M S, F S$, and $S E X$ on the choice of sectoral

Duration of Unemployment," Review of Economics and Statistics, Vol. 59, No. 3 (August 1977), pp. 26971.

"Jonathan Silberman and Garey Durden, "Determining Legislative Preferences on Minimum Wage: An Economic Approach," Journal of Political Economy, Vol. 84, No. 2 (April 1976), pp. 317- 29.

12Ibid. 
Table. Estimated Probit Results from Equations 1 and $\mathrm{l}^{\prime}$.

(Asymptotic $t$-values are in parentheses)

\begin{tabular}{|c|c|c|c|c|}
\hline & \multicolumn{2}{|c|}{ Probit Coefficients } & \multicolumn{2}{|c|}{ Partial Derivatives } \\
\hline & (1) & $\left(1^{\prime}\right)$ & (1) & $\left(l^{\prime}\right)$ \\
\hline Constant & $\begin{array}{l}-4.626^{* *} \\
(-9.049)\end{array}$ & $\begin{array}{c}-3.586^{* *} \\
(-12.475)\end{array}$ & - & - \\
\hline ED & $\begin{array}{l}0.061^{* *} \\
(4.545)\end{array}$ & $\begin{array}{l}0.061^{* *} \\
(4.110)\end{array}$ & 0.005 & 0.005 \\
\hline AGE & $\begin{array}{l}0.070^{* *} \\
(2.906)\end{array}$ & - & 0.005 & - \\
\hline $\mathrm{AGE}^{2}$ & $\begin{array}{l}-0.0008^{* *} \\
(-2.750)\end{array}$ & - & -0.00005 & - \\
\hline EXP & - & $\begin{array}{l}0.035^{* *} \\
(2.830)\end{array}$ & - & 0.002 \\
\hline $\mathbf{E X P}^{2}$ & - & $\begin{array}{l}-0.0006^{* *} \\
(-2.578)\end{array}$ & - & -0.00004 \\
\hline MS & $\begin{array}{c}0.017 \\
(0.104)\end{array}$ & $\begin{array}{c}0.019 \\
(0.114)\end{array}$ & 0.0009 & 0.001 \\
\hline FS & $\begin{array}{c}0.012 \\
(0.567)\end{array}$ & $\begin{array}{c}0.016 \\
(0.767)\end{array}$ & 0.005 & 0.001 \\
\hline RACE & $\begin{array}{l}0.381^{* *} \\
(4.119)\end{array}$ & $\begin{array}{l}0.373^{* *} \\
(4.048)\end{array}$ & 0.029 & 0.029 \\
\hline SEX & $\begin{array}{c}0.122 \\
(0.722)\end{array}$ & $\begin{array}{c}0.132 \\
(0.784)\end{array}$ & 0.0009 & 0.010 \\
\hline RA & $\begin{array}{l}0.104^{* *} \\
(3.691)\end{array}$ & $\begin{array}{l}0.106^{* *} \\
(3.787)\end{array}$ & 0.008 & 0.008 \\
\hline $\begin{array}{l}-2 \times \log \\
\text { Likelihood Ratio }\end{array}$ & $72.01^{* *}$ & $70.90^{* *}$ & & \\
\hline
\end{tabular}

**Statistically significant at the one percent level or better.

employment is zero. The estimated coefficient on RACE, however, is statistically significant at the one percent level or better, implying that the probability of public sector employment is 2.9 percentage points greater for blacks than for whites. This finding is consistent with the findings of other studies $^{13}$ and suggests an awareness of, and rational response to, the lesser degree of racial discrimination in the public sector.

The estimated coefficient on $R A$ is positive and statistically significant at the one percent level or better. Since the risk aversion index is measured ordinally rather than cardinally, there is no meaningful "per unit change" interpretation that can

${ }^{13}$ James Long, "Public-Private Sectoral Differences in Employment Discrimination," Southern Economic Joumal, Vol. 42, No. 1 (July 1975), pp. 89-96. be given to the numerical value of its estimated partial derivative. Nevertheless, our results do indicate that, as hypothesized, innately risk-averse individuals have a greater probability of choosing public sector than private sector employment. ${ }^{14}$

\section{Concluding Remarks}

Our results seem to suggest that laborforce participants correctly perceive that less risk is attached to public sector employment, and that they act on this information. Specifically, the more value the individual places on the job security associated with

\footnotetext{
${ }^{14}$ It should be pointed out that although the coefficient of $R A$ is very significant, its value is small; hence, the probability of choosing the public sector is only $7.2 \%$ higher for those at the upper end of the range of observation on risk aversion than for those at the lower end.
} 
public sector employment, the greater his tendency to seek employment in the public sector.

One important implication follows from this conclusion. If, as is usually assumed,,$^{15}$ markets are dominated by risk averters, then theory suggests that, ceteris paribus, equal pay between the public and private sectors would generate an excess supply of labor to the public sector. Stated otherwise, equal net advantage would require lower pay rates in public employment than in private employment for workers with comparable human capital. Hence, studies such as those by Smith may understate the extent of "overpayment" of public sector workers unless there is reason to believe that other nonpecuniary factors are more favorable in the

${ }^{15}$ See, for example, Allan King, "Occupational Choice, Risk Aversion, and Wealth," Industrial and Labor Relations Review, Vol. 27, No. 4 (July 1974), pp. $586-96$. public sector, which would contradict the findings of Quinn. ${ }^{16}$

Recognition of this fact clarifies an apparent anomaly. Smith's finding that males in local and state government are underpaid relative to their counterparts in the private sector is inconsistent with the common perception that there are queues of applicants for most state and local government jobs. ${ }^{17}$ Yet if this apparent "underpayment" is in reality a negative equalizing difference associated with the higher degree of job stability (and other desirable job characteristics) in these sectors, no inconsistency exists. Indeed, where queues are formidable, it is logical to conclude that the negative equalizing difference is perhaps not sufficiently large.

${ }^{16}$ Quinn, "Wage Differentials Among Older Workers," pp. 41-62.

${ }^{17}$ Smith, "Government Wage Differentials by Sex," Table 1, pp. $793-94$. 
Copyright of Industrial \& Labor Relations Review is the property of Cornell University and its content may not be copied or emailed to multiple sites or posted to a listserv without the copyright holder's express written permission. However, users may print, download, or email articles for individual use. 